\title{
KEARIFAN LOKAL BUDAYA MINANGKABAU DALAM SENI PERTUNJUKAN TRADISIONAL RANDAI
}

Local Wisdom of Minangkabau Culture in Traditional Performing Arts "Randai"

\author{
Iswadi Bahardur \\ STKIP PGRI Sumatera Barat \\ Pos el: iswadi70bahardur70@gmail.com
}

\begin{abstract}
Naskah Diterima 20 Agustus 2018-Direvisi Akhir 27 November 2018-Disetujui 30 November 2018 doi.org/10.26499/jentera.v7i2.932
\end{abstract}

\begin{abstract}
Abstrak: Seni pertunjukan tradisional memuat beragam unsur kearifan lokal masing-masing etnisnya. Demikian juga dengan seni pertunjukan tradisional randai dari Minangkabau. Falsafah adat dan agama yang dianut masyarakat Minangkabau terhimpun dalam randai. Namun, sampai saat ini kajian terhadap randai Minangkabau masih dominan pada aspek etika dan estetika sebagai seni tari dan seni pertunjukan teater. Kajian kearifan lokal budaya Minangkabau dalam randai masih sedikit dieksplorasi. Dilatarbelakangi hal tersebut, penelitian ini bertujuan menggali dan menganalisis unsur-unsur kearifan lokal budaya Minangkabau yang terdapat dalam seni pertunjukan tradisional randai. Proses penelusuran literatur dan penelaahan kembali berbagai hasil kajian randai, baik dari aspek estetika gerak dan tari, musik, gerak silat, lakon, dan naskah cerita menghasilkan simpulan bahwa randai Minangkabau memuat ragam unsur kearifan lokal yang bersumber dari ajaran agama, adat, serta falsafah alam. Temuan ini membuktikan bahwa masyarakat Minangkabau adalah masyarakat yang kaya akan seni tradisi dan berkehidupan dilandasi oleh ajaran agama, adat, serta kepedulian terhadap alam semesta.
\end{abstract}

Kata kunci: budaya, kearifan lokal, Minangkabau, randai, seni tradisi

Abstract: Traditional performing arts contain various elements of the local wisdom of each ethnic group. Likewise with traditional Minangkabau randai performing arts. The customary philosophy and religion adopted by the Minangkabau people are gathered in randai. However, until now the study of Minangkabau randai is still dominant in the aspects of ethics and aesthetics as dance and theater performance. The study of the local wisdom of the Minangkabau culture in Randai is still little explored. Against this background, this study aims to explore and analyze the local wisdom elements of Minangkabau culture found in traditional randai performing arts. The literature search process and a review of various results of smart studies, both from the aesthetic aspects of motion and dance, music, martial arts movements, plays, and storytelling produce conclusions that Minangkabau randai contains a variety of elements of local wisdom originating from the teachings of religion, customs, and natural philosophy. This finding proves that the Minangkabau community is a society that is rich in traditional arts and life based on the teachings of religion, customs, and concern for the universe. Keywords: culture, local wisdom, Minangkabau, randai, traditional arts. 
How to cite: Bahardur, Iswadi (2018). Kearifan Lokal Budaya Minangkabau dalam Seni Pertunjukan Tradisional Randai. Jentera: Jurnal Kajian Sastra, 7 (2), 145-160. (https://doi.org/10.26499/jentera.v7i2.932)

\section{PENDAHULUAN}

Seni pertunjukan tradisional merupakan bagian dari budaya lokal yang memuat beragam unsur kearifan budaya lokal. Di dalamnya terhimpun ilmu pengetahuan, baik nilai-nilai ajaran moral, religi, pendidikan, maupun unsur-unsur yang bersifat kebendaan sebagai sebuah warisan kebudayaan (Prayogi \& Endang Danial, 2016: 63). Dengan adanya muatan beragam nilai tersebut, seni pertunjukan tradisional berfungsi sebagai penuntun dan pembawa pesan moral untuk masyarakat pemiliknya (Seha, et al, 2014: 112).

Dilihat dari sudut pandang estetika dan etika, seni tradisi turut menjadi alat pengucapan komunikasi emosi estetis antarmanusia terkait dengan pengalaman dan perasaan yang memiliki nilai seni untuk keselarasan hubungan sosial berlandaskan keyakinan bersama (Murniati, 2015:26; Sedyawati, 2006:124). Seni tradisi etnis Minangkabau, contohnya, memiliki keberagaman unsur estetika dan etika kultural yang mencerminkan komunikasi manusia dengan alam yang bersifat normatif (Rustiyanti, at. all, 2013; Hasanuddin, 2015).

Permasalahannya saat ini, perkembangan teknologi global mulai mengikis nilai-nilai kearifan budaya lokal. Memang tidak dapat dipungkiri, kemajuan teknologi berpengaruh positif pada terbentuknya trend budaya berbasis teknologi digital, tetapi fenomena tersebut memembawa dampak pada berkurangnya apresiasi masyarakat terhadap seni tradisional (Ngafifi, 2014; Rustiyanti, 2014).

Seni tradisional sangat identik dengan kearifan budaya lokal. Melalui eksistensi pertunjukannya, seni tradisi merepresentasikan kehidupan masyarakat lokal yang ditopang oleh keluhuran budi yang arif, bijaksana, keteladanan, dan cendekia. Contoh seni tradisional yang mencerminkan hal tersebut adalah randai Minangkabau.

Randai Minangkabau berasal dari permainan rakyat generasi muda (dalam istilah di Minangkabau adalah anak nagari) zaman tradisional. Navis (2015: 276) menjelaskan, istilah randai kemungkinan berasal dari kata andai-andai dengan awalan bar-sehingga menjadi berandai-andai yang artinya berangkaian secara berturut-turut atau suara yang bersahut-sahutan. Sumber lain, Kayam (dalam Zulkifli, 2013: 32) menyatakan, istilah 
randai berasal dari bahasa Arab, yaitu rayan-li-da-I yang sangat dekat dengan kata da-I, ahli dakwah dari gerakan tarekat Naqsyahbandiyah.

Randai adalah gambaran identitas masyarakat Minangkabau yang sangat kuat dengan falsafah, etika, dan pelajaran hidup orang Minang yang berpusat pada alam semesta (Primadesi, 2013: 179). Randai menggambarkan kearifan lokal masyarakat Minangkabau, melekat pada fisik sekaligus batin individu yang membentuk keutuhan masyarakat bernagari. Nilai-nilai kesenian tradisional dalam randai menjadi representasi norma dan kebiasaan yang berlaku di masyarakat Minang; kesenian dianggap rancak (bagus, elok) apabila tidak menyimpang dari norma adat, dan kebiasaan yang berlaku dalam masyarakat Minangkabau (Arzul, 2015: 108). Unsur dialog dalam randai, misalnya, menjadi satu unsur yang bermuatan nilai-nilai karakter kerja sama komunikatif dan patut dipahami dan ditanamkan kepada generasi muda (Arzul, 2015:113). Selain itu, kompleksitas unsur seni pertunjukan meliputi sastra, kaba, musik, tari, gerak silat, tari, dan dendang menguatkan alasan perlunya untuk dilestarikan (Primadesi, 2013; Wulandari, 2015).

Permasalahan lain yang penting dicermati, saat ini seni pertunjukan randai di Minangkabau masih didominasi oleh eksplorasi dari segi seni hiburan saja. Pertunjukan randai oleh kelompok-kelompok kesenian randai memang masih terus berlangsung, namun masih berkisar sebagai seni pertunjukan saja. Demikian juga halnya dengan kajian ilmiah akademis terhadap randai Minangkabau, saat ini masih dominan pada aspek etika dan estetika seni tari dan teater saja. Kajian terhadap unsur-unsur nilai dan kearifan budaya lokal Minangkabau dalam randai masih kurang. Fakta tersebut menunjukkan perlunya langkah percepatan kajian ke arah tersebut sebelum randai terdiskriminasi oleh budaya asing. Dengan asumsi, untuk membuka jalan ke arah tersebut, maka penelitian ini bertujuan menggali dan menganalisis kearifan lokal budaya Minangkabau yang terdapat dalam seni pertunjukan tradisional randai. Diharapkan kajian ini akan menjadi bagian dari upaya akademik untuk menggali kearifan lokal dalam seni pertunjukan tradisional serta langkah lanjut untuk pelestariannya yang belum ada sebelumnya.

Relevan dengan permasalahan tersebut, beberapa peneliti lain telah mengkaji randai dalam ragam konteks dan sudut pandang penelitian. Penelitian yang mengkaji kesenian randai dilihat dari estetika tari Minangkabau dilakukan oleh Rustiyanti (2014), 
yang menyatakan bahwa dilihat dari aspek estetika tari, randai bagi masyarakat Minangkabau diartikan sebagai olah gerak dan rasa yang dikenal dengan istilah pamenan (permainan).

Syuriadi dan Hasanuddin WS (2014) meneliti Nilai-nilai Pendidikan dalam Teks Cerita Randai “Malangga Sumpah” Karya Lukman Bustami Grup Randai Bintang Tampalo Kenagarian Padang Laweh Kabupaten Sijunjung. Hasil penelitian ini menyimpulkan bahwa nilai-nilai pendidikan dalam naskah randai tersebut mencakup nilai religius, nilai pendidikan ketangguhan, nilai pendidikan kepedulian, serta nilai-nilai kejujuran. Selanjutnya Primadesi (2013) memfokuskan kajian penelitiannya pada cara preservasi pengetahuan dalam pertunjukan randai Minangkabau. Preservasi tersebut meliputi sosialisasi, kombinasi, eksternalisasi, dan internalisasi. Dari model preservasi tersebut disimpulkannya bahwa pewarisan pengetahuan randai Minangkabau dapat dilakukan dengan cara sosialisasi, yaitu interaksi antara anak randai dengan tetua-tetua dalam kelompok randai. Kechot (2009) meneliti sejarah perkembangan randai dan unsur-unsur randai Minangkabau di Negeri Sembilan Malaysia. Sementara itu, Suryadi (2014) meneliti studi kasus Randai sebagai genre seni pertunjukan di Minangkabau dalam konteks industri rekaman dan kebudayaan di Indonesia. Suryadi menyimpulkan bahwa dalam perkembangannya randai merupakan satu di antara genre seni tradisi yang dilestarikan melalui rekaman ke dalam bentuk cakram compact disk $(\mathrm{CD})$.

Terkait dengan penelitian yang telah ada tersebut, penelitian ini dilakukan dengan fokus kajian kearifan lokal budaya Minangkabau. Penggunaan nama randai Minangkabau didasari alasan bahwa randai juga terdapat di Negeri Sembilan, Malaysia dan di Riau.

\section{LANDASAN TEORI}

Kearifan lokal (local wisdom) merupakan satu perangkat pandangan hidup, ilmu pengetahuan, dan strategi kehidupan yang berwujud dalam aktivitas yang dilakukan oleh masyarakat local, yang mampu menjawab berbagai masalah dalam pemenuhan kebutuhan mereka (Fajarini, 2014; Saputra, 2011; Cheng, 2002; Triyanto, 2017). Kearifan lokal menjadi pengetahuan dasar dari kehidupan, didapatkan dari pengalaman ataupun kebenaran hidup, bisa bersifat abstrak atau konkret, diseimbangkan dengan 
alam serta kultur milik sebuah kelompok masyarakat tertentu (Mungmachon, 2012: 174). Kearifan lokal juga dapat ditemukan, baik dalam kelompok masyarakat maupun pada individu.

Kearifan lokal digunakan oleh masyarakat sebagai pengontrol kehidupan sehari-hari dalam hubungan keluarga, dengan sesama saudara, serta dengan orang-orang dalam lingkungan yang lebih luas (Kamonthip \& Kongprasertamorn, 2007: 2). Oleh karena cakupannya adalah pengetahuan, budaya, dan kecerdasan pengetahuan lokal, maka kearifan lokal dikenal juga dengan istilah local knowledge, local wisdom, atau genious local. Adapun karakteristik kearifan lokal, yaitu (1) harus menggabungkan pengetahuan kebajikan yang mengajarkan orang tentang etika dan nilai-nilai moral; (2) kearifan lokal harus mengajar orang untuk mencintai alam, bukan untuk menghancurkannya; dan (3) kearifan lokal harus berasal dari anggota komunitas yang lebih tua (Mungmachon, 2012:174).

Kearifan lokal dapat berbentuk nilai, norma, etika, kepercayaan, adat-istiadat, hukum, adat, aturan-aturan khusus. Selanjutnya, nilai-nilai yang relevan dengan kearifan lokal, antara lain nilai kejujuran, tanggung jawab, disiplin, kreatif, serta kerja keras (Haryanto, 2014: 212). Dalam karya seni, khususnya seni tradisional, kearifan lokal akan tercermin dalam bahasa, baik secara lisan maupun tulis; pepatah, pantun, nyanyian, atau petuah.

Berdasarkan sejarahnya, seni pertunjukan tradisional berawal dari upacara dan ritual keagamaan tradisional yang bersifat magis, disampaikan dalam bentuk mantra-mantra secara berulang (Sastrowardoyo, 1995; Hasanuddin, 1996). Di Indonesia, upacara dan ritual keagamaan tersebut menjadi cikal bakal seni pertunjukan teater tradisional dengan adanya perpaduan unsur gerak dan musik. Pertunjukan tersebut diyakini sebagai bentuk keyakinan batin pada alam dan pencipta, sekaligus sebagai bentuk eksistensi berkesenian (Kayam, 1981; Ninuk, 2000). Awal menjadi seni pertunjukan teater tradisional, dimulai sebagai teater tanpa naskah dan kuat unsur-unsur kedaerahannya (Samidi, 2006: 237). Dalam perkembangannya, eksistensi teater tradisional, seperti Makyong (Kepulauan Riau), Mendu (Kalimantan), Topeng Betawi (Betawi), serta Randai (Sumatera Barat) dijadikan sebagai hiburan pelipur lara (Hasanuddin, 1996: 27-29). 
Di Sumatera Barat randai dikenal sebagai seni pertunjukan tradisional yang memadukan unsur musik, tari, gerak, dan cerita. Esten (dalam Sedyawati, 1983) menjelaskan randai adalah salah satu bentuk seni pertunjukan tradisional masyarakat Minangkabau yang sering dipertunjukkan dalam acara profan seperti pesta panen, pesta perkawinan, pesta perhelatan penghulu, serta acara serupa lainnya. Randai memiliki unsur-unsur struktur yang esensial, yaitu (a) adanya unsur tarian atau improvisasi yang berfungsi sebagai pemenggal adegan selanjutnya yang disebut galombang atau gelombang; (b) dendang yang berfungsi untuk menyampaikan cerita, disebut gurindam; serta (c) cerita sebagai rangkaian tubuh peristiwa yang dilakonkan. Dari segi fungsi, randai berfungsi sebagai (a) alat pendidikan moral bagi masyarakat; (b) alat untuk membina dan mengembangkan rasa solidaritas antarmasyarakat pemiliknya, (c) wadah produktif untuk menciptakan kesegaran kondisi mentalitas anggota masyarakat, dan (d) wadah untuk mengungkapkan problema perasaan.

Seni pertunjukan tradisional berawal dari upacara-upacara dan ritual keagamaan masyarakat tradisional. Upacara-upacara dan ritual keagamaan tersebut bersifat magis, disampaikan dalam bentuk mantra-mantra, secara berulang, dan dianggap memiliki nilai magis (Hasanuddin, 1996: 28-29). Di Indonesia, upacara dan ritual keagamaan tersebut menjadi cikal bakal seni pertunjukkan teater tradisional setelah ditambah dengan unsur gerak dan musik. Pelaku pertunjukannya adalah orang tertentu yang diyakini memiliki kekuatan batin dan supranatural, seperti pawang dalam pertunjukan Makyong di Riau. Pertunjukan tersebut diyakini sebagai bentuk keyakinan batin pada alam dan pencipta, sekaligus sebagai bentuk eksistensi berkesenian (Kayam, 1981; Ninuk, 2000).

Ritual-ritual keagamaan tersebut menjadi cikal bakal lahirnya seni pertunjukan tradisional jenis teater tradisional di berbagai daerah di Indonesia. Teater tradisional tersebut memulai sejarah kelahirannya sebagai taeter tanpa naskah yang sangat kuat unsur-unsur kedaerahannya (Samidi, 2006: 237). Dalam masa awal, teater tradisional tanpa naskah tersebut dijadikan unsur seni hiburan dan tujuan pelipur lara dalam keterbatasan akses kebudayaan masyarakat tradisional (Oemarjati, 1991: 19). Dalam pertumbuhan tersebut teater tradisional tanpa naskah memiliki beragam jenis di Indonesia. 
Esten (dalam Sedyawati, 1983) menjelaskan randai adalah salah satu bentuk seni pertunjukan tradisional masyarakat Minangkabau yang sering dipertunjukan dalam acara profan seperti pesta panen, pesta perkawinan, pesta perhelatan penghulu, serta acara serupa lainnya. Selanjutnya, menurut Esten, randai memiliki unsur-unsur struktur yang esensial, yaitu (a) adanya unsur tarian atau improvisasi yang berfumgsi sebagai pemenggal adegan selanjutnya yang disebut galombang atau gelombang; (b) dendang yang berfungsi untuk menyampaikan cerita yang tidak sempat dilakonkan di arena, disebut gurindam; (c) cerita sebagai rangkaian batang tubuh peristiwa yang dilakonkan. Jika dilihat dari segi fugsinya, randai berfungsi sebagai (a) alat pendidikan moral bagi masyarakat; (b) alat untuk membina dan mengembangkan rasa solidaritas antarmasyarakat pemiliknya, (c) wadah produktif untuk menciptakan kesegaran kondisi mentalitas anggota masyarakat, dan (d) wadah untuk mengungkapkan problema perasaan.

Navis (2015: 276) menyatakan bahwa randai dengan lakon dan cerita, pertama kali muncul dimulai di daerah Payakumbuh, bertepatan setelah kemunculan pementasan randai Cindur Mato. Pendapat lain, Zulkifli (2013; Wendy 2014) menyatakan, secara etnodramaturgi randai terdiri dari dua aspek pagelaran, yaitu a) teks pergelaran randai; dan b) teks lakon randai. Seturut dengan itu, menurut Wendy (2014: 42-44) dilihat dari teks pergelaran randai terdapat tiga aspek fundamental, yakni a) aspek galombang; b) aspek dendang; dan c) aspek carito-buah kato.

Aspek galombang, yaitu komposisi gerak berkeliling dalam format lingkaran yang disebut pamain galombang. Aspek dendang (gurindam), yaitu komposisi vokal yang dilakukan oleh 2 sampai 3 orang yang disebut Tukang Dendang, sebagai wujud menarasikan setiap bagian transisi sambungan (legaran tagak) dalam penceritaan randai. Aspek carito-buah kato, yaitu tatanan pemeranan oleh sejumlah pamain carito (sebutan untuk laki-laki) dan biduan (sebutan untuk perempuan). Buah kato adalah daya tutur dalam format pantun dan gurindam sebagai upaya mewujudkan penceritaan (carito) yang telah disusun menjadi bagian-bagian cerita (legaran duduak) tertentu.

\section{METODE PENELITIAN}

Metode penelitian yang digunakan adalah library research (penelitian kepustakaan). Penelitian ini tidak bersifat studi lapangan, tetapi dilakukan dengan literature review 
atas data-data tertulis. Data-data tersebut adalah dokumen-dokumen hasil kajian terhadap randai serta referensi-referensi tertulis lainnya yang terkait dengan permasalahan tersebut. Posisi peneliti dalam library research ini bukan semata membaca, mencatat, dan merangkum hasil-hasil kajian randai yang telah ada, tetapi peran peneliti adalah merumuskan sebuah temuan baru terkait fenomena dan gejala-gejala baru yang ditemukan berdasarkan hasil analisis. Data yang dikumpulkan selanjutnya dikaji dan dianalisis kembali sehingga dihasilkan temuan baru. Maka dalam konteks ini peneliti mengkaji hasil-hasil penelitian terdahulu serta referensi-referensi tentang randai untuk menghasilkan sebuah temuan permasalahan baru terkait dengan kearifan lokal budaya Minangkabau dalam randai.

\section{PEMBAHASAN}

Kearifan lokal adat Minangkabau merupakan warisan budaya yang ada di masyarakat, yang mana pelaksanannya dilakukan secara turun-menurun oleh masyarakat yang bersangkutan. Sumbernya adalah kebudayaan matrilineal yang dianut masyarakat Minangkabau dan tertuang dalam beragam aturan adat. Kearifan lokal tersebut umumnya berisi ajaran untuk memelihara dan memanfaatkan sumber daya alam sehingga wajar masyarakat Minangkabau memiliki falsafah alam takambang jadi guru. Kearifan lokal tersebut mengejawantah dalam karya seni, nilai moral, adat istiadat, dan serangkaian pola hidup sehari-hari. Sebagai karya seni tradisional, kearifan lokal budaya Minangkabau yang termuat dalam randai tercakup dalam unsur gerak galombang, tari, silek (silat), dialog (naskah yang didasari oleh bentuk kaba (kabar) yang berbentuk pantun berbahasa daerah Minangkabau), serta asal-usul kelompok randai. Kearifan lokal tersebut seperti dibahas pada bagian berikut.

\subsection{Sambah Silek sebagai Cermin Filosofi Adat Basandi Syarak-Syarak Basandi Kitabullah (ABS-SBK)}

Seperti halnya kebudayaan dalam suku bangsa lain di berbagai daerah, kebudayaan di Minangkabau juga terbentuk dari sistem religi, pengetahuan, sistem kemasyarakatan, bahasa, kesenian, mata pencaharian, serta sistem teknologi peralatan. Hal mendasar dalam ketujuh unsur tersebut dalam budaya Minangkabau adalah sistem religi. Sistem religi menjadi penopang sistem pengetahuan dan unsur lain. 
Kekerabatan Matrilineal yang diterapkan di Minangkabau juga didasari oleh sistem religi Islam. Oleh karena itu, adat Minangkabau berjalan dengan pedoman hidup adat basandi syarak-syarak basandi kitabullah (ABS-SBK). Pengejawantahan nilai-nilai dalam ABS-SBK tercermin dalam kehidupan sehari-hari. Syarak yang berarti hukum, khususnya hukum adat, menjadi landasan yang berjalan beririmgan dengan hukum Islam (kitabullah). Itu sebabnya setiap aktivitas dalam sosial kemasyarakatan dan berkesenian di Minangkabau senantiasa berhubungan dengan penerapan ajaran Islam dan ajaran adat. Selaras dengan hal itu, gerak randai, pada bagian tertentu adalah cerminan dari sistem religi Islam (kitabullah) yang dianut oleh masyarakat Minangkabau.

Pertunjukan randai di Minangkabau selalu dibuka dengan sambah silek. Sambah silek adalah gerak awal untuk sebuah penghormatan yang dilakukan oleh anak-anak randai (sebutan untuk pemain randai) untuk Tuhan dan kepada penonton. Sambah silek dilakukan sebelum anak randai membentuk gerak galombang dalam legaran. Sambah silek yang dipertunjukkan oleh anak randai tergantung pada aliran silat yang dianut oleh kelompok randai tersebut. Sebagai contoh, gerak silek kumango (silat Kumango). Gerak silek Kumango dalam sambah silek berasal dari aliran silek Kumango. Silek kumango adalah salah satu aliran ilmu silat yang berasal dari Kampung Kumango, Kabupaten Tanah Datar. Aliran ini adalah aliran silat tua yang tumbuh dan berkembang di lingkungan surau (mushalla), dikembangkan oleh Syekh Abdurahman Al Khalidi yang dikenal sebagai Syekh Kumango (Saputra, 2011: 75).

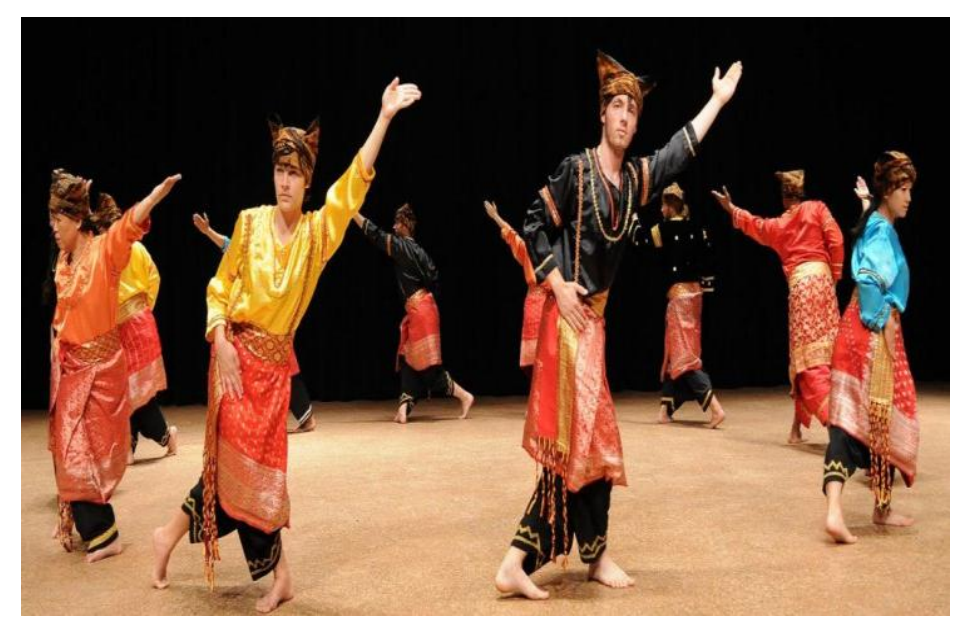

Gambar 1: Pemain Teater Randai dalam Komposisi Galombang (dokumentasi penulis saat pertunjukkan Randai kunjungan budaya) 
Gerak sambah silek pada masing-masing kelompok randai tidaklah sama, selalu memiliki ragam gaya dan aliran sendiri, seperti terungkap dalam pepatah petitih adaik salingka nagari, pusako salingka kaum, lain guru lain ajaran. Maksudnya, setiap daerah memiliki aturan adat sendiri, dan setiap guru silat memiliki pelajaran sendiri. Filosofi dari sambah silek dalam randai mengandung nilai-nilai kearifan lokal budaya Minangkabau alam takambang jadi guru yang menandakan bahwa adat dan laku masyarakat Minangkabau tidak bisa dilepaskan dari tuntuan ajaran agama Islam. Kitab suci Alquran sebagai kitab suci umat Islam menjadi landasan dalam menetapkan dan menjalankan adat di Minangkabau. Sembah (hormat) yang ditujukan kepada Tuhan adalah cermin nilai-nilai agama, sedangkan gerak silat Kumango adalah cermin bahwa manusia di Minangkabau belajar dari fenomena dan berbagai unsur yang terdapat di alam semesta. Hal ini menggambarkan bahwa masyarakat Minangkabau adalah suku bangsa yang hidup dalam tuntunan adat basandi syarak-syarak basandi kitabullah (ABS-SBK).

\subsection{Carito Buah Kato sebagai Cermin Filosofi Kato Nan Ampek}

Bagi masyarakat Minangkabau, adat adalah pegangan dalam bergaul dalam kehidupan sehari-hari. Adat dijadikan sebagai peraturan hidup yang mengikat orang per orang dan masyarakat untuk tunduk dan mematuhinya (Amir, 2007: 73). Selain adat istiadat yang mengatur perihal kebiasaan dan tradisi di tiap daerah, komponen adat lainnya adalah limbago nan sapuluah. Limbago nan sapuluah adalah sebuah aturan adat yang khusus dan merupakan ketentuan yang berlaku umum, baik di ranah Minangkabau maupun di rantau. Bagian aturan dalam limbago nan sapuluah tersebut adalah kato nan ampek. Kato nan ampek adalah aturan tata krama dalam berkomunikasi antara sesama masyarakat Minangkabau dari berbagai usia. Kato nan ampek meliputi kato-kato mandaki, kato mandata, kato melereang, kato manurun (Amir, 2007: 76).

Dalam permainan randai kurenah kato nan ampek selalu menjadi bagian tata krama berbicara yang diperankan oleh anak-anak randai. Biasanya kato nan ampek mengejawantah dalam bentuk dialog dan pantun-pantun. Ciri khas dialog antartokoh menggunakan bahasa yang santun, mencerminkan kesopanan dan sikap saling menghormati antarsesama, baik antara orang yang lebih tua dengan orang yang berusia lebih muda, atau sebaliknya. Hal ini adalah salah satu ciri identitas manusia 
Minangkabau dalam bertutur kata. Berikut ini adalah contoh dialog berbentuk pantun dalam randai yang mencerminkan kearifan lokal kato nan ampek.

Taleh karanji urang gagak

Bao barang ka tapian

Nak kanduang kamari tagak

Adoh nan barang dikatokan

Talas Karanji sarang gagak

dibawa ke tepian

Anak kandung mari berdiri

Ada sesuatu yang hendak disampaikan

Dialog tersebut adalah pantun yang disampaikan oleh tokoh Ayah kepada anaknya. Konteks dialog tersebut adalah orang yang lebih tua dengan yang lebih muda usianya, serta kedudukan orang tua dengan anaknya. Kurenah kato yang digunakan adalah kato manurun. Dalam kato manurun biasanya pihak yang berusia lebih tua tetap harus menyampaikan bahasa yang sifatnya membimbing dan memberi petunjuk tanpa bahasa kasar. Prinsip kurenah kato manurun saat seseorang yang berusia tua kepada yang lebih muda tergambar dari bahasa yang halus dan sangat menjunjung sikap menghargai. Apabila sebuah pertunjukan randai telah menyajikan dialog tokoh demikian dengan sendirinya telah mengajarkan pada penonton sikap saling menghormati dan sopan santun dalam berkomunikasi dengan siapa saja.

\subsection{Budi Bahasa Minang sebagai Cermin Identitas Diri Urang Minang}

Bahasa Minangkabau adalah ciri identitas lokalitas Minangkabau. Bahasa daerah Minangkabau adalah bahasa ibu masyarakat Minangkabau, digunakan sebagai pengantar dalam komunikasi sehari-hari, di luar dari penggunaan bahasa nasional. Sebagai bahasa ibu, suku Minangkabau memperoleh bahasa Minangkabau secara alamiah tanpa proses belajar di sekolah seperti halnya bahasa kedua. Tentu sebagai bahasa ibu, bahasa Minangkabau menjadi penciri identitas kolektif suku dan perekat hubungan kekerabatan. Dalam konteks kultural, bahasa daerah Minangkabau adalah satu bagian kearifan lokal suku Minangkabau. Dalam penerapannya di tengah masyarakat Minangkabau, bahasa tersebut mengandung banyak ajaran falsafah kehidupan, khususnya tentang tata cara berkomunikasi antarindividu dan antarkelompok yang dilandasi kebijakan dan kearifan adat. 
Randai Minangkabau adalah seni tradisi yang menggunakan bahasa Minangkabau sebagai pengantar dalam naskah cerita. Dalam sejarah performansi randai, pertama kali ditampilkan pada tahun 1930-an telah menggunakan bahasa daerah Minangkabau. Sampai saat ini randai yang berkembang di Sumatera Barat tetap menggunakan bahasa Minangkabau. Berdasarkan fakta tersebut dapat dianalisis bahwa terdapat nilai kearifan lokal yang diajarkan dalam setiap pertunjukan randai. Nilai kearifan tersebut adalah agar masyarakat Minangkabau senantiasa menjaga kelestarian bahasa daerah sendiri, menggunakan untuk komunikasi antarsesama orang suku Minangkabau, serta menyebarluaskannya untuk berbagai kepentingan bersama.

\subsection{Falsafah Hidup Alam Takambang Jadi Guru sebagai Pedoman Hidup}

Falsafah alam Minangkabau menempatkan manusia sebagai salah satu unsur yang statusnya sama dengan unsur lainnya, seperti tanah, rumah, suku, dan nagari. Persamaan status tersebut dilihat dari keperluan budi daya manusia itu sendiri. Setiap manusia secara bersama-sama atau sendiri-sendiri memerlukan tamah, rumah, suku, dan nagari sebagaimana mereka memerlukan manusia atau orang lain untuk kepentingan lahir dan batinnya (Navis, 2015: 59). Filosofi inilah yang disebut dengan alam takambang jadi guru.

Makna dari falsafah ini adalah kehidupan manusia tidak dapat dipisahkan dari alam dan segala unsurnya. Kehidupan manusia selalu berpasang-pasangan, seperti halnya unsur-unsur di alam semesta yang selalu berpasangan; siang-malam, laut-udara, langit-bumi, air-api, kehidupan-kematian, dan sebagainya. Sebagai bagian dari ekosistem alam, manusia dituntut mampu bertahan dalam kehidupan dan menjaga alam. Manusia juga dituntut cakap dalam membaca dan mempelajari semua tanda-tanda alam. Demikian masyarakat Minangkabau memaknai alam dan kehidupan.

Dalam pertunjukan randai Minangkabau juga termuat falsafah alam takambang jadi guru tersebut. Berbagai gerak silat dan galombang yang diperagakan oleh anak randai merupakan bagian dari hasil olahan guru tuo silek dalam kelompok randai setelah mempelajari berbagai fenomena kejadian alam beserta aktivitas makhluk hidup lainnya. Hal ini menguatkan alasan munculnya berbagai aliran ilmu silat yang menjadi dasar dalam gerak galombang randai. Seperti halnya gerak silat aliran Kumango, salah satu gerak silat yang digunakan dalam randai, sedikit banyaknya terinspirasi dari alam. 


\subsection{Gerak Silek dalam Randai sebagai Cermin Identitas Anak Nagari ${ }^{1}$}

Gerakan-gerakan galombang dan legaran dalam randai merupakan bagian dari gerakan pencak silat. Gerakan pembuka yang disebut sambah silek, gerakan langkah silek (balabek) dan gerakan akhir langkah silek pada dasarnya adalah representasi dari gerakan dalam silat yang terus berkembang dengan memadukan pertunjukan jurus silat yang dilengkapi dengan dendang dan musik. Melalui bentuk ini secara langsung randai telah mencerminkan kearifan lokal masyarakat Minangkabau sebagai masyarakat yang identik dengan silat.

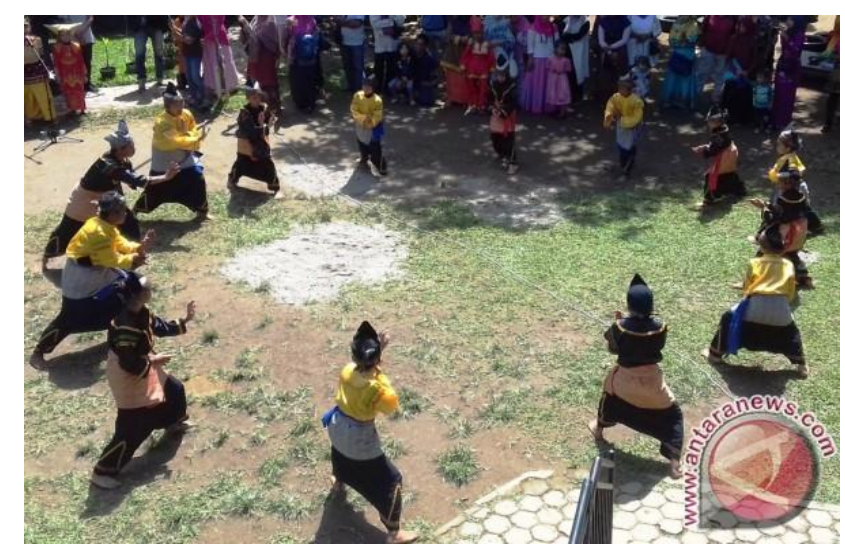

Gambar 2: Komposisi Anak Randai dalam Gerak Silek dan Lakon (Sumber: dokumentasi antaranews.com saat pertunjukkan randai SMA di Banuhampu)

\subsection{Bakaba dalam Randai sebagai Identitas Sosial Masyarakat Minangkabau}

Sebelum tradisi tulis masuk ke dalam masyarakat Minangkabau, masyarakat tradisional identik dengan tradisi lisan. Kaba (kabar) adalah tradisi lisan di Minangkabau, dijadikan sebagai alat komunikasi, penyampai berbagai informasi berita di nagari. Kaba pada masa tradisional berbentuk pantun dan berbahasa daerah Minangkabau. Dalam ranah kesusasteraan lisan milik Minangkabau, kaba juga memiliki fungsi sebagai pelipur lara. Fungsi tersebut sudah ada sejak kemunculan kaba di rantau pesisir dan selanjutnya sampai ke daerah darek (darat).

Hal yang cukup unik di masa awal kemunculan kaba adalah hadirnya figur mamak dalam hampir semua teks kaba. Figur mamak dalam setiap kaba menjadi sosok yang membawa pesan-pesan kemuliaan sistem adat. Hal tersebut menjadi sebuah cerminan bahwa kaba memang didukung oleh sistem sosial Minangkabau. Fakta-fakta tentang

\footnotetext{
${ }^{1}$ Nagari merupakan kesatuan kelompok komunal masyarakat Minangkabau, yang ruang lingkupnya lebih besar dari korong atau kampung
} 
substansi dan fungsi kaba di masa tradisional ternyata juga menjadi bagian penting dalam randai. Unsur teks lisan, figur mamak, pesan-pesan budaya dan agama yang semula terdapat dalam kaba saat ini juga menjadi unsur pembentuk keutuhan dalam pertunjukkan randai.

Bakaba dalam pertunjukan randai dapat ditemukan dalam bagian dendang dan carito kato. Susunan bait-bait dendang dalam randai yang sarat dengan pantun serta dialog antartokoh, juga berbentuk pantun merupakan bagian dari kaba. Dikaitkan dengan fungsi kaba dalam masyarakat tradisional Minangkabau, maka kearifan lokal yang termaktub dalam kaba berkonteks randai adalah pesan moral agar masyarakat Minangkabau selalu saling berkomunikasi dengan sesama etnis Minangkabau. Hal itu selaras dengan mamangan orang Minangkabau yang berbunyi, kaba baik bahimbauan, kaba buruak bahambauan.

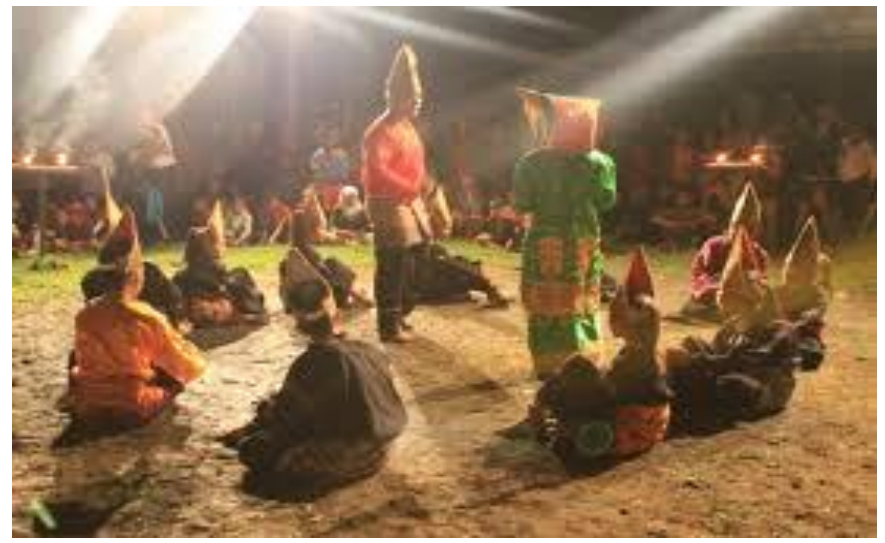

Gambar 3: Anak randai dalam komposisi berdialog (Sumber: dokumentasi penulis)

Apabila di masa awal pertumbuhannya teks kaba dalam randai tidak dituliskan, pada masa selanjutnya naskah pertunjukan randai yang berbentuk kaba telah dituliskan. Meskipun demikian, patut dipahami bahwa secara tidak langsung unsur kaba dalam randai menjadi bagian dari kearifan lokal masyarakat Minangkabau yang mencerminkan identitas setempat.

\section{PENUTUP}

Randai merupakan seni pertunjukan tradisi dalam kebudayaan masyarakat Minangkabau. Meskipun tergolong sebagai seni tradisional, randai memiliki nilai-nilai 
sejarah kebudayaan yang sangat penting untuk dikenal generasi muda. Di samping nilai-nilai sejarah, randai juga sarat dengan unsur kearifan lokal yang mencerminkan identitas budaya Minangkabau. Berdasarkan analisis yang telah dilakukan, disimpulkan kearifan lokal budaya Minangkabau yang terdapat dalam randai meliputi a) sambah silek sebagai cermin filosofi adat basandi syarak-syarak basandi kitabullah; b) carito buah kato dalam randai sebagai cermin filosofi kato nan ampek; c) bahasa Minangkabau dalam randai sebagai cermin identitas diri; d) falsafah hidup alam takambang jadi guru sebagai pedoman hidup; e) gerak silek randai sebagai cermin identitas anak nagari, dan f) bakaba dalam randai sebagai identitas sosial berpedoman pada pentingnya muatan nilai kearifan lokal tersebut patut dilakukan pelestarian dan pemertahanan randai di tengah pesatnya berbagai seni budaya modern yang masuk ke dalam lapisan kehidupan masyarakat Minangkabau.

\section{DAFTAR PUSTAKA}

Arzul. (2015). "Nilai-nilai Pendidikan Karakter dalam Randai Bujang Sampai". Jurnal Peradaban Melayu, (10), 108-122.

Cheng, Yin Cheong. (2002). "Foster Local Knowledge and Wisdom In Globalized Education: Multiple Theories". Proceeding International Conference on Globalization and Localization Enmeshed: Searching For Balance In Education. Faculty of Education of Chulalongkorn University. 18-21 November 2002. Thailand. $1-36$.

Fajarini, Ulfah. (2014). "Peranan Kearifan Lokal dalam Pendidikan Karakter". Jurnal Sosio Didaktika, 1 (2), 123-130.

Haryanto, Triu Joko. (2014. "Kearifan Lokal Pendukung Kerukunan Beragama Pada Komunitas Tengger Malang Jatim”. Jurnal Analisa, 21 (02), 201-213

Hasanuddin. (1996). Drama Karya dalam Dua Dimensi, Kajian Teori, Sejarah dan Analisis. Jakarta: Angkasa.

Hasanuddin. (2015). "Kearifan Lokal dalam Tradisi Lisan Kepercayaan Rakyat Ungkapan Larangan Kanak-kanak Masyarakat Minangkabau Wilayah Adat Luhak Nan Tigo". KEMBARA: Jurnal Keilmuan Bahasa, Sastra, dan Pengajarannya, 1 (2), 198-204.

Kamonthip dan Kongprasertamorn. (2007). "Local Wisdom, Environmental Protection and Community Development: The Clam Farmers In Tambon Bangkhunsai, Phetchaburi Province Thailand. Manusya: Journal of Humanities, 10 (1), 1-10.

Kayam, Umar. (1981). Seni, Tradisi, Masyarakat. Jakarta: Sinar Harapan.

Kechot, Abd. Samad Bin. (2009). "Kajian Randai Warisan Masyarakat Minang Negeri Sembilan: Meneroka Perkembangan dan Taburannya”. Jurnal Melayu. 4, $161-172$.

M.S, Amir. (2007). Adat Minangkabu, Pola dan Tujuan Hidup Orang Minang. Jakarta: Mutiara Sumber Widya. 
Mungmachon, Mmiss Roikhwanput. (2012). "Knowledge and Local Wisdom: Community Treasure". International Journal of Humanities and Social Science, 2 (13), 174-181.

Murniati. (2015). "Dekonstruksi Estetika dan Makna Musik Gamat di Sawahlunto, Sumatera Barat". Jurnal Resital, 16 (1), 25-35.

Navis, A.A. (2015). Alam Takambang Jadi Guru. Padang. Grafika Jaya sumbar.

Ngafifi, Muhammad. (2014). "Kemajuan Teknologi dan Pola Hidup Manusia dalam Perspektif Sosial Budaya". Jurnal Pembangunan Pendidikan, 2 (1), $33-47$.

Ninuk, Kleden. (2000). "Teater Tradisional sebagai Dokumen Komunitas". Jurnal Antropologi Indonesia, 62 (2), 23-32.

Primadesi, Yona. (2013). "Preservesi Pengetahuan dalam Tradisi Lisan Seni Pertunjukan Randai di Minangkabau Sumatera Barat”. Jurnal Kajian Informasi dan Perpustakaan, 1 (2), 179-187.

Prayogi, Ryan dan Endang Danial. (2016). "Pergeseran Nilai-nilai Budaya pada Suku Bonai Sebagai Civic Culture di Kecamatan Bonai Darussalam Kabupaten Rokan Hulu Provinsi Riau". Jurnal HUMANIKA, 23 (1), 61-79.

Rustiyanti, Sri, at. all. (2013). "Estetika Tari Minang dalam Kesenian Randai Analisis Tekstual Kontekstual". Jurnal Seni dan Budaya Panggung, 23 (1), 42-55.

Rustiyanti, Sri. (2014). "Seni Tradisi Randai dengan Pembacaan Masa Kini”. Prosiding Seminar Nasional Riset Inovatif II.

Samidi. (2006). "Teater Tradisional di Surabaya1950-1965". Jurnal Humaniora, 18 (3), $23-33$.

Saputra, Isral. (2011). "Silek Kumango: Keberadaan, Pewarisan, dan Kearifan Lokal Minangkabau”. Wacana Etnik; Jurnal Ilmu Sosial dan Humaniora, 2 (1), 73 - 94.

Sedyawati, Edi dan Sapardi Djoko Damono (Editor). (1983). Seni dalam Masyarakat Indonesia. Jakarta: Sinar Harapan.

Sedyawati, Edi. (2006). Budaya Indonesia: Kajian Arkeologi, Seni, dan Sejarah. Jakarta: PT RAJA Grafindo Persada.

Seha, Nur, et al. (2014). "Fungsi Teater Rakyat Ubrug Bagi Masyarakat Banten". Atavisme, 17 (1). 107-120.

Syuriadi, Helki dan Hasanuddin WS. (2014). "Nilai-nilai Pendidikan dalam Teks Cerita Randai "Malangga Sumpah" Karya Lukman Bustami Grup Randai Bintang Tampalo Kenagarian Padang Laweh Kabupaten Sijunjung". Jurnal Bahasa, Sastra dan Pembelajaran, 2 (2), 60-74.

Suryadi. (2014). The Recording Industry And 'Regional' Culture In Indonesia The Case of Minangkabau. Disertasi. Universiteit Leiden.

Triyanto. (2017). "Art Education Based on Local Wisdom". Proceeding of $2^{\text {nd }}$ International Conference of Arts Languange And Culture. Universitas Sebelas Maret, 33-39.

Wendy. (2014). "Dramaturgi Teater Rakyat Randai di Minangkabau”. Jurnal Kajian Seni. 01 (01), 42-52.

Wulandari, Yosi. (2015). "Randai sebagai Komunikasi Sastra Daerah di Minangkabau Sebuah Gagasan Melestarikan Budaya Indonesia". Prosiding Konferensi Nasional Bahasa dan Sastra III.

Zulkifli. (2013). "Randai sebagai Teater Rakyat Minangkabau: Alternatif Pembinaan dan Pengembangan”. Jurnal Garak jo Garik, I (9), 32-32. 